\title{
Academic Staff Personal Variables and Utilization of ICT Resources for Research Teaching and Records Management in Higher Education
}

\author{
Francisca N. Odigwe, University of Calabar, Nigeria \\ Valentine Joseph Owan, University of Calabar, Nigeria
}

The European Conference on Education 2020

Official Conference Proceedings

\begin{abstract}
There is currently an academic debate among researchers regarding the influence of age and gender on ICT utilisation generally among lecturers. This study was designed to contribute to this debate and open up new paths to areas on which researchers have focused little or no attention. This study examined lecturers' variables (gender, age, educational qualification and rank) and the utilisation of ICT resources for teaching, research, and records management in higher education. The study adopted a descriptive survey design. The study's population comprised of 9,604 lecturers at the University of Calabar. A total of 313 lecturers who were available in their offices during data collection responded to a questionnaire which was designed by the researchers. Major findings showed that the extent of lecturers' utilisation of ICT for teaching, research, and records management is significantly low. Also, staff educational qualification, rank, gender, and age significantly influence the utilisation of ICT for teaching, research and records management. Also, the utilisation of ICT resources decreased with lecturers' educational qualifications, rank and age; male lecturers were more competent in the use of ICT resources than females. It was concluded that lecturers' variables play a significant role on the extent to which they utilise ICT resources for teaching, research and records management in higher education. This study creates a new path of innovation in education on which prospective researches could focus.
\end{abstract}

Keywords: Age, Gender, ICT Utilisation, Qualification, Rank, Teaching, Research

\section{iafor}

The International Academic Forum

www.iafor.org 


\section{Introduction}

The field of education has been affected by the penetrating influence of ICTs worldwide. ICT has made an impact on the quality and quantity of teaching, learning and research in institutions of higher learning. The role ICT plays on the human population generally and education particularly, cannot be overemphasized. As such, lecturers in higher education should not ignore this important role. This is because lecturers who utilize ICT services maximally would be able to boost their knowledgebase and use ICT in the planning, presentation, and delivery of effective lessons. The optimal use of ICT could also improve the efficiency of lecturers in carrying out research beginning from sourcing literature materials, data collection and analysis, to the preparation of research reports, correspondence and publication (Odigwe et al., 2020; Owan \& Bassey, 2019). On the other hand, those who do not utilize ICTs services adequately may become outdated, lacking current information and skills needed in their areas of speciality. This may compel them to depend on traditional methods of instructional delivery, records management and research. The introduction of ICT, especially the internet, has brought great changes to the world which have affected the way man communicates with others.

The utilization of ICT in the classroom facilitates effective teaching, reinforces lecturers' ability to cater for learners with diverse learning needs, fosters learners' active involvement and participation in the instructional process, and promotes good grasp of lesson contents. This helps them (lecturers) transfer their ideas, feelings, and thoughts to learners, which in turn, contributes to the good academic performance of both students and educational institutions. In the $21^{\text {st }}$ century, there is a growing concern in educational institutions regarding the use of ICTs to promote teaching and inculcate good skills in the learners. People are now able to interact with others across the globe without distance and time constraints due to the growth of ICT (Owan et al., 2020). Today, information is freely sourced and received at the speed of light. Access to modern and 'state of the art' libraries are now possible through the internet where quality, current and reliable research information can be obtained (Nwankwoala, 2015). ICT has been reported to increase lecturers' activeness in the delivery of quality and productive teaching in the classroom (Gusen, et al., 2005). Thus, lecturers with a high level of ICT competence are more effective than those with moderate and low levels of ICT competence respectively, in areas such as communication, research/publication, record-keeping/management and classroom instruction (Akpan, 2014). This implies that the level of ICT skills possessed by lecturers significantly enhanced their service delivery and job efficiency.

The integration of ICT resources into the classroom context has attracted a lot of attention globally. A study has shown that universities with very good ICT resources, achieved on the average, better results in teaching subjects than those with poor ICT resources (Ayeni \& Ogubameru, 2013). Therefore, lecturers are expected to give considerable attention to the selection and use of appropriate ICT resources to stimulate students' interest in meaningful learning. Recognising the need to integrate ICT tools and services into education, spurred many scholars in the past have attempted to explain the role and importance of ICT in education variably (AbdulSalaam, 2012; Archibong, et al., 2010; Basri, et al., 2018; Buza \& Mula, 2017; Collis \& Moonen, 2001; Ghavifekr \& Rosdy, 2015; John, 2015; Jumbo, 2019; Maisamari, et al., 2018; Munir \& Khan, 2015; Owulu, et al., 2016). Though there is a gradual 
increase in the use of ICTs in Nigeria and many African countries, much is already known concerning how ICTs are used in advanced nations of the world in performing sophisticated tasks. In Africa, it is clear that teachers' and students' accessibility to ICT in some schools are at the 'grass-root' stages due to the inadequate supply of ICT resources (Chiware, 2006).

Consequently, there is a shortfall in lecturers knowledge on the use of many simple ICT gadgets in almost all developing nations, which affect their educational standard towards global competitiveness (Maisamari, et al., 2018). In Nigeria, some universities are faced with different challenges on the utilisation of ICT among lecturers (Sani et al., 2016). One of such challenge is that many senior lecturers are without basic ICT skills and knowledge of computer operation (Abdulrazaq, 2016; Ehikhamenor, 2002; Ejinkeonye \& Usoroh, 2016; Emeasoba \& Nweke, 2016; Maisamari, et al., 2018) which affect the quality of their service. This has also made available ICT services and resources to be underutilized. At a time when technology has developed so much that personal computers are affordable, it is quite disheartening that many staff do not own these gadgets and only a few owners tend to be using them appropriately. Through interaction with some staff, it was discovered that most lecturers seldom utilise ICT resources because they believe that such tools are meant for younger generations. It was based on these prevailing issues that a need for a study to assess the personal variables of lecturers and how they possibly influence the utilization of ICT resources in higher education was conceived. Lecturers' variables such as, gender, age, educational qualification and rank were considered due to the perceived variation in the use of ICT resources among lecturers with different characteristics.

There is a growing body of research on gender and the utilisation of ICT by lecturers in higher and secondary levels of education (Alba \& Trani, 2018; Emeasoba \& Nweke, 2016; Etim, 2019; Fomsi \& Orduah, 2017; Kpolovie \& Awusaku, 2015; Lubis et al., 2017; Manyilizu \& Gilbert, 2015; Unegbu, et al.,2015). Gender disparity on the utilisation of ICT resources has also been widely studied (Alakpodia, 2014; Mahdi \& Al-Dera, 2013; Onasanya, et al., 2010; Sanda \& Kurfi, 2013), indicating the widespread attention that it has received. Most of these studies showed that there is a significant influence of gender on ICT usage by lecturers (e.g. Lubis, et al, 2017; Emeasoba \& Nweke, 2016; Alakpodia, 2014; Sanda \& Kurfi, 2013; Mahdi \& AlDera, 2013; Soffer \& Raban, 2013; Ramayah et al., 2013). More specifically, some studies have provided evidence suggesting or indicating that a higher proportion of male lecturers utilise ICT resources than female (Etim, 2019; Mahdi \& Al-Dera, 2013; Manyilizu \& Gilbert, 2015).

Some studies argue that significant differences exist in the utilisation of ICT tools between male and female lecturers (Alba \& Trani, 2018; Fomsi \& Orduah, 2017; Kpolovie \& Awusaku, 2015; Onasanya et al, 2010); implying that gender significantly influences lecturers' utilisation of ICT. However, there was no indication of the extent to which ICT was utilised by male and female lecturers. In bridging this gap, a study showed that male and female lecturers utilise ICT tools at the same rate (Unegbu et al, 2015). Contrastingly, another study submitted that female staff utilise ICT resources more than males (Wong, et al., 2015). This indicates that there is an ongoing argument is ongoing in the literature among scholars regarding the effect of gender on ICT utilisation. Another problem that warranted the inclusion of gender to 
the present study is that past studies paid more attention to the utilisation of ICT resources general without specifying the areas of utilisation. This study is the first to streamline utilisation into three functional areas of ICT application in higher education, while also contributing to the debate.

The attention of many scholars has been drawn to examine the influence of age on the utilisation of ICT in higher education (Alba \& Trani, 2018; Albion et al., 2011; Amua-sekyi \& Asare, 2016; Jegede, 2009; Lubis et al., 2017; Mazoya et al., 2015; Unegbu et al., 2015). Some studies held that age is a significant predictor of lecturers' utilisation of ICT in higher institutions of learning (Albion, et al., 2011; Lubis et al., 2017), others held to the contrary, that age does not significantly predict ICT usage (Alba \& Trani, 2018; Amua-sekyi \& Asare, 2016; Etim, 2019; Jegede, 2009; Mazoya et al, 2015; Unegbu et al., 2015). It can be inferred from the literature that age is widely known to be uncorrelated with the utilisation of ICT. Howver, the few opposite findings from a relatively few studies present a case that warrants further research in the area of age and ICT utilisation. Age was considered in this study as a response to this call, to clarify the inconclusive arguments with a piece of new evidence from the perspective of Africa. To the researchers' knowledge, other personal variables of lecturers such as rank and educational qualification have not received any attention from previous studies. Thus, little or nothing is known yet about their effect on the utilisation of ICT resources. After a thorough literaure search, we conclude to best of our knowledge, that this study is the first to examine the effect of lecturers' educational qulaification and rank on ICT utilisation, specifically for research, teaching and records. Against this backdrop, this study was designed to fill some of these gaps and extend the works of previous studies while also contributing to the ongoing debate.

\section{Statement of hypotheses}

The following null hypotheses were formulated and tested in this study.

1. The extent of lecturers' utilisation of ICT resources for teaching, research and records management respectively, is not significantly high.

2. Lecturers' educational qualification has no significant influence on the utilisation of ICT resources for teaching, research and records management.

3. There is no significant influence of lecturers' ranks on the utilisation of ICT resources for teaching, research and records management.

4. Lecturers gender does not significantly influence the utilisation of ICT resources for teaching, research and records management

5. There is no significant influence of lecturers' age on the utilisation of ICT resources for teaching, research and records management in higher education.

\section{Methods}

The design adopted for the study was a descriptive survey design. This research was carried out in one federal university in Nigeria (University of Calabar). The population of this study comprised 9,604 currently employed lecturers distributed across 16 Faculties (Academic Planning Unit, University of Calabar, 2019). This population range from graduate assistants to Professors of the university. Multi-stage sampling technique was adopted by the researchers in selecting the sample of the study. In achieving this, 31\% (five faculties) of the available 16 faculties in the 
University of Calabar were selected. From each selected faculty, four departments were randomly selected using the simple random sampling technique. In each of the selected departments, only the lecturers that were intact in their offices at the time of data collection were given the questionnaire to complete. A total of 313 lecturers were available in their offices during the data collection process and constitute the sample of this study (see Table 1)

\begin{tabular}{lcc}
\hline Faculties & No. of departments selected & No. of lecturers studied \\
\hline Arts & 4 & 58 \\
Education & 4 & 87 \\
Medicine & 4 & 39 \\
Physical Sciences & 4 & 56 \\
Social Sciences & 4 & 73 \\
Total & 20 & 313 \\
\hline
\end{tabular}

Source: Field survey (2019).

Table 1: Sample distribution of the study showing the number of lecturers selected from five faculties in the university

The instrument used for data collection was a questionnaire entitled: "Academic Staff Personal Variables and Utilization of ICT Resources Questionnaire (ASPVUICTRQ)." This was designed by the researchers and structured into two sections. Section A elicited the demographic information of respondents while Section B was designed with 21 four-points Likert-scale items measuring lecturers utilisation of ICT services for teaching ( 7 items), research ( 7 items) and records management (7 items). The instrument received face and content validity from three psychometric experts in the Department of Educational Foundations, University of Calabar, Calabar. Test-retest reliability method was used in ascertaining the internal consistency of the instrument, with a coefficient of .893 affirming that the instrument is reliable. The researchers visited the selected departments after obtaining permission from departmental heads. With the help of some non-lecturers in the general offices of each selected department, the researchers were able to locate the offices of all academic staff. Those at their offices at the time of data collection who were willing to participate, were given copies of the instrument to fill. Staff were duly informed of the importance of the exercise and the need to provide honest responses to the instruments. The respondents were also assured that the data requested would be treated with total confidentiality. Respondents were not allowed to take copies of the instrument home to avoid issues of loss and retrieval difficulties.

\section{Results}

\section{Respondents' demographic information}

A total of 313 lecturers participated in the study, males were 141(45.05\%) and $172(54.95 \%)$ were females. A total of 17 lecturers $(5.43 \%)$ were less than 30 years old, 132(42.17\%) were between 30 - 49 years and $164(52.40 \%)$ were either 50 years or above. Out of the 313 respondents, 19(6.07\%) were Graduate Assistants, 28 (8.95\%) were Assistant Lecturers, 91(29.07\%) were Lecturer IIs, 96(30.67\%) were Lecturer Is, 39 (12.46\%) were Senior Lecturers, 25(8\%) were Associate Professors, and $15(4.79 \%)$ were Professors. Furthermore, 14(4.47\%) of the respondents were first 
degree holders, 182(58.15\%) were Masters' degrees holders, while 117(37.38\%) had a PhD.

\section{Hypothesis one}

The extent of lecturers' utilisation of ICT resources for teaching, research and records management respectively, is not significantly high. This hypothesis was tested at the .05 alpha level using population t-test (see Table 2 ).

\begin{tabular}{lcccccc}
\hline Variables & $\mathrm{N}$ & $\overline{\mathrm{X}}$ & $\mathrm{SD}$ & $\overline{\mathrm{X}}$ diff & t calc. & Sig. \\
\hline Utilisation of ICT for teaching & 313 & 50.35 & 17.655 & .348 & .349 & .727 \\
Utilisation of ICT for Research & 313 & 47.34 & 15.929 & 2.665 & $2.959^{* *}$ & .003 \\
Utilisation of ICT for Records mgt & 313 & 49.01 & 16.890 & .987 & 1.034 & .302 \\
$\begin{array}{l}\text { Overall utilisation of ICT } \\
\text { resources }\end{array}$ & 313 & 48.90 & 16.084 & 1.101 & 1.211 & .227 \\
\hline
\end{tabular}

**Significant at the .01 level; Test Value $=50.00 ; \mathrm{Df}=312$

Table 2: Population t-test results showing the extent of lecturers' utilisation of ICT resources for teaching, research and records management in higher education

The results in Table 2 show that staff utilisation of ICT resources for teaching is higher than the level of expectation, while utilisation for research and records management are below the expected level. Comparatively, the results show further that lecturers utilise ICT resources more for teaching, before records management and research. However, the extent of utilisation for teaching is not significantly high $(\mathrm{t}=$ $0.349, \mathrm{p}=.727)$. The extent of utilisation for research is significantly low $(\mathrm{t}=2.959, \mathrm{p}$ $=.003)$, while utilisation for records management is not significantly low $(\mathrm{t}=1.034, \mathrm{p}$ $=.302$ ). Generally, the mean utilisation of ICT resources in higher education is 48.90 which is below the test value of 50.00 with a mean difference of 1.101 . The t- and pvalues of 1.211 and .337 indicate that the mean differences are not significant. Thus, we retain the null hypothesis and conclude that the extent of lecturers' utilisation of ICT resources for teaching, research and records management respectively, is not significantly high in higher education.

\section{Hypothesis two}

Lecturers' educational qualification has no significant influence on the utilisation of ICT resources for teaching, research and records management. Lecturers' educational qualification which is the independent variable of this hypothesis was measured across three nominal levels (First degree, Masters' degree, and Doctorate), while the dependent variables were continuously measured at the interval scale. The one-way analysis of variance statistical technique was considered most appropriate in testing the null hypothesis at the .05 level of significance (see Table 3 ).

\begin{tabular}{lcccc}
\hline Staff Qualification & $\mathrm{N}$ & $\overline{\mathrm{X}}$ & $\mathrm{SD}$ & $\mathrm{SE}$ \\
\hline First Degree & 14 & 70.93 & 11.809 & 3.156 \\
Masters' Degree & 182 & 55.82 & 15.533 & 1.151 \\
Doctorate Degree & 117 & 39.37 & 15.048 & 1.391 \\
Total & 313 & 50.35 & 17.655 & .998 \\
\hline
\end{tabular}




\begin{tabular}{llccccc}
\hline Utilisation of ICT & Source of variation & SS & Df & MS & F & Sig. \\
\hline For Teaching & Between Groups & 25494.543 & 2 & 12747.271 & 55.073 & .000 \\
& Within Groups & 71752.499 & 310 & 231.460 & & \\
& Total & 97247.042 & 312 & & & \\
For Research & Between Groups & 13165.803 & 2 & 6582.902 & 30.921 & .000 \\
& Within Groups & 65997.973 & 310 & 212.897 & & \\
For Records & Total & 79163.776 & 312 & & & \\
management & Between Groups & 19188.449 & 2 & 9594.224 & 42.602 & .000 \\
& Within Groups & 69813.500 & 310 & 225.205 & & \\
Overall & Total & 89001.949 & 312 & & & \\
Utilisation & Between Groups & 18912.863 & 2 & 9456.432 & 47.435 & .000 \\
& Within Groups & 61800.266 & 310 & 199.356 & & \\
\hline
\end{tabular}

TABLE 3: One-way analysis of variance results showing the influence of lecturers' educational qualification on the utilisation of ICT resources for teaching, research and records management in higher education

The ANOVA section of Table 3 presents the specific and overall results of lecturers' utilisation of ICT resources in higher education. The results indicate that there is a significant influence of lecturers' educational qualification on the utilisation of ICT resources for teaching $\{\mathrm{F}(2,310)=55.073, \mathrm{p}<.05\}$, research $\{\mathrm{F}(2,310)=30.921, \mathrm{p}$ $<.05\}$ and records management $\{\mathrm{F}(2,310)=42.602, \mathrm{p}<.05\}$. In terms of the overall utilisation of ICT resources in higher education (where teaching, research and records management stood as proxies), the results in Table 3 reveals a significant influence of staff educational qualification on ICT utilisation $\{\mathrm{F}(2,310)=47.435, \mathrm{p}<.05\}$. Upon this discovery, the null hypothesis was rejected while the alternative hypothesis is upheld. This implies that lecturers of various educational qualifications, differed in their utilisation of ICT resources for various purposes (teaching, research and records management.

\section{Hypothesis three}

There is no significant influence of lecturers' ranks on the utilisation of ICT resources for teaching, research and records management. The independent variable of this null hypothesis is lecturers' rank which is further operationalized into seven levels including Graduate Assistant, Assistant Lecturer, Lecturer II, Lecturer I, Senior Lecturer, Associate Professor, and Professor. The dependent variables of this hypothesis (utilization of ICT resources for teaching, research and records management) was measured continuously at the interval level. One-way analysis of variance was employed as the statistical technique in testing the null hypothesis at the .05 level of significance (see Table 4). The result in Table 4 suggests that graduate assistants are the most effective in the utilisation of ICT services. This is followed by assistant lecturers, lecturer IIs, lecturer Is, senior lecturers, associate professors, and professors in that order. Although, a further test needs to be performed to ascertain whether the observed mean differences are significant or not. The analysis of variance results presented in Table 4 reveals that there is a significant influence of staff rank on the utilisation of ICT resources for teaching $\{\mathrm{F}(6,306)=71.527, \mathrm{p}<.05\}$, research $\{\mathrm{F}(6,306)=33.698, \mathrm{p}<.05\}$ and records management $\{\mathrm{F}(6,306)=58.245, \mathrm{p}<.05\}$. When ICT utilisation is considered from a general perspective, the result in Table 4 indicates a significant influence of staffers rank on ICT utilisation $\{\mathrm{F}(6,306)=$ 
$60.173, \mathrm{p}<.05\}$. By implication, there is a significant influence of lecturers' rank on the utilization of ICT resources generally, and specifically, in terms of teaching, research and records management in higher education.

\begin{tabular}{|c|c|c|c|c|c|c|}
\hline Staff rank & $\mathrm{N}$ & $\overline{\mathrm{X}}$ & \multicolumn{2}{|r|}{ SD } & \multicolumn{2}{|c|}{ SE } \\
\hline Graduate Assistants & 19 & 71.68 & \multicolumn{2}{|c|}{9.615} & \multicolumn{2}{|c|}{2.206} \\
\hline Assistant Lecturers & 28 & 70.64 & \multicolumn{2}{|c|}{11.295} & \multicolumn{2}{|c|}{2.135} \\
\hline Lecturer IIs & 91 & 60.71 & \multicolumn{2}{|c|}{12.248} & \multicolumn{2}{|c|}{1.284} \\
\hline Lecturer Is & 96 & 44.13 & \multicolumn{2}{|c|}{10.767} & \multicolumn{2}{|c|}{1.099} \\
\hline Senior Lecturers & 39 & 37.10 & \multicolumn{2}{|c|}{11.896} & \multicolumn{2}{|c|}{1.905} \\
\hline Associate Professors & 25 & 31.68 & \multicolumn{2}{|c|}{12.229} & \multicolumn{2}{|c|}{2.446} \\
\hline Professors & 15 & 27.93 & \multicolumn{2}{|c|}{11.616} & \multicolumn{2}{|c|}{2.999} \\
\hline Total & 313 & 50.35 & \multicolumn{2}{|c|}{17.655} & \multicolumn{2}{|c|}{.998} \\
\hline Utilisation of ICT & Source of variation & SS & Df & $\mathrm{MS}$ & $\mathrm{F}$ & Sig. \\
\hline \multirow[t]{3}{*}{ For Teaching } & Between Groups & 56769.473 & 6 & 9461.579 & 71.527 & .000 \\
\hline & Within Groups & 40477.568 & 306 & 132.280 & & \\
\hline & Total & 97247.042 & 312 & & & \\
\hline \multirow[t]{3}{*}{ For Research } & Between Groups & 31496.047 & 6 & 5249.341 & 33.698 & .000 \\
\hline & Within Groups & 47667.729 & 306 & 155.777 & & \\
\hline & Total & 79163.776 & 312 & & & \\
\hline For Records & Between Groups & 47452.209 & 6 & 7908.702 & 58.245 & .000 \\
\hline \multirow[t]{2}{*}{ Management } & Within Groups & 41549.740 & 306 & 135.783 & & \\
\hline & Total & 89001.949 & 312 & & & \\
\hline \multirow[t]{3}{*}{ Overall utilisation } & Between Groups & 43686.275 & 6 & 7281.046 & 60.173 & .000 \\
\hline & Within Groups & 37026.855 & 306 & 121.003 & & \\
\hline & Total & 80713.130 & 312 & & & \\
\hline
\end{tabular}

Table 4: One-way ANOVA results showing the influence of lecturers' rank on the utilisation of ICT resources for teaching, research and records management in higher education

\section{Hypothesis four}

Lecturers' gender does not significantly influence the utilisation of ICT resources for teaching, research and records management. This hypothesis was tested at .05 level of significance using the independent t-test statistical technique. The result of the analysis is presented in Table 5 .

\begin{tabular}{llcccccc}
\hline Utilisation of ICT & Staff gender & $\mathrm{N}$ & $\overline{\mathrm{X}}$ & $\mathrm{SD}$ & $\overline{\mathrm{x}}$ diff & Calc. t & Sig \\
\hline For teaching & Male & 141 & 58.72 & 16.703 & $15.241^{* *}$ & 8.404 & .000 \\
& Female & 172 & 43.48 & 15.331 & & & \\
For Research & Male & 141 & 53.28 & 15.843 & $10.824^{* *}$ & 6.347 & .000 \\
& Female & 172 & 42.46 & 14.295 & & & \\
Records & Male & 141 & 56.73 & 16.267 & $14.044^{* *}$ & 8.030 & .000 \\
management & Female & 172 & 42.69 & 14.645 & & & \\
Overall utilisation & Male & 141 & 56.25 & 14.925 & $13.370^{* *}$ & 8.026 & .000 \\
& Female & 172 & 42.88 & 14.444 & & & \\
\hline
\end{tabular}

**Significant at the .01 alpha level; $\mathrm{df}=311$; Critical $\mathrm{t}=1.968$

Table 5: Independent t-test results showing the influence of staff gender on the utilization of ICT resources in higher education 
The result presented in Table 5 indicates that male lecturers utilised ICT resources more than female generally and specifically, for teaching, research and records management in higher education. The overall results in Table 5 show that males utilise ICT resources for general purposes more than females with a mean difference of 8.036. A cursory look also at the results in Table 5 shows that all the p-values across the various dimensions are below the alpha level of .05 at 311 degrees of freedom. Based on this result, the null hypothesis was rejected while the alternative hypothesis was retained. The implication is that lecturers' gender significantly influences the utilisation of ICT resources for teaching, research and records management in higher education.

\section{Hypothesis five}

There is no significant influence of lecturers' age on the utilisation of ICT resources for teaching, research and records management in higher education. Staff' age in this hypothesis has three levels while the dependent variable was measured continuously. One-way analysis of variance was employed as the statistical tool for testing this null hypothesis at the .05 level of significance (see Table 6).

\begin{tabular}{|c|c|c|c|c|c|c|}
\hline Staff age & $\mathrm{N}$ & $\overline{\mathrm{x}}$ & \multicolumn{2}{|c|}{$\mathrm{SD}$} & \multicolumn{2}{|c|}{ SE } \\
\hline Less than 30 years & 17 & 67.47 & \multicolumn{2}{|c|}{15.637} & \multicolumn{2}{|c|}{3.793} \\
\hline $30-49$ years & 132 & 58.43 & \multicolumn{2}{|c|}{16.660} & \multicolumn{2}{|c|}{1.450} \\
\hline 50 - years and above & 164 & 42.07 & \multicolumn{2}{|c|}{14.037} & \multicolumn{2}{|c|}{1.096} \\
\hline Total & 313 & 50.35 & \multicolumn{2}{|c|}{17.655} & \multicolumn{2}{|c|}{.998} \\
\hline Utilisation of ICT & Source of variation & SS & $\mathrm{df}$ & MS & $\mathrm{F}$ & Sig. \\
\hline \multirow[t]{3}{*}{ For Teaching } & Between Groups & 24856.158 & 2 & 12428.079 & 53.221 & .000 \\
\hline & Within Groups & 72390.884 & 310 & 233.519 & & \\
\hline & Total & 97247.042 & 312 & & & \\
\hline \multirow[t]{3}{*}{ For Research } & Between Groups & 13165.803 & 2 & 6582.902 & 30.921 & .000 \\
\hline & Within Groups & 65997.973 & 310 & 212.897 & & \\
\hline & Total & 79163.776 & 312 & & & \\
\hline Records & Between Groups & 19188.449 & 2 & 9594.224 & 42.602 & .000 \\
\hline \multirow[t]{2}{*}{ management } & Within Groups & 69813.500 & 310 & 225.205 & & \\
\hline & Total & 89001.949 & 312 & & & \\
\hline \multirow[t]{3}{*}{ Overall utilisation } & Between Groups & 18912.863 & 2 & 9456.432 & 47.435 & .000 \\
\hline & Within Groups & 61800.266 & 310 & 199.356 & & \\
\hline & Total & 80713.130 & 312 & & & \\
\hline
\end{tabular}

Table 6: One-way analysis of variance results of the influence of staff' age on the utilization of ICT resources for teaching, research and records management in higher education

The results as presented in Table 6 show that in terms of the utilization of ICT resources generally, staff with ages less than 30 years had the highest mean $(\overline{\mathrm{X}}=$ $67.47)$, this is followed by those between $30-49$ years $(\overline{\mathrm{X}}=58.43)$, and those who are 50 years or above $(\overline{\mathrm{X}}=42.07)$, in that order. A look at the analysis of variance section of Table 5, indicates that there is a significant influence of staff age on the utilisation of ICT resources for teaching $\{\mathrm{F}(2,310)=53.221, \mathrm{p}<.05\}$, research $\{\mathrm{F}(2,310)=$ $30.921, \mathrm{p}<.05\}$ and records management $\{\mathrm{F}(2,310)=42.602, \mathrm{p}<.05\}$. Treating utilisation from a general context, the result in Table 6 indicates that staff age 
significantly influences their utilisation of ICT resources in higher education $\{\mathrm{F}(2$, $310)=47.435, p<.05\}$. Based on these results, the null hypothesis was rejected while the alternate hypothesis is retained. This implies that there is a significant influence of lecturers' age on the utilisation of ICT resources generally and specifically, for teaching, research and records management in higher education.

\section{Discussion of findings}

It was discovered through the first finding of this study that the extent of lecturers' utilisation of ICT generally and for teaching, research, and records management is significantly low. A higher proportion of lecturers tend to use ICT tools for teaching more than records management and research. The reason for this finding may be attributed to either the poor availability and access to ICT resources or the unwillingness of many staff to adjust to societal dynamics. This finding agrees with the results of previous studies (Abdul-Salaam, 2012; Archibong, et al., 2010; Basri, et al., 2018; Buza \& Mula, 2017; Collis \& Moonen, 2001; Ghavifekr \& Rosdy, 2015; John, 2015; Maisamari, et al., 2018; Munir \& Khan, 2015) which concluded that there is a low level of ICT utilisation across different African countries.

The second finding of this study established that there is a significant influence of staff' educational qualification on the utilization of ICT resources for teaching, research and records management in higher education. This finding suggests that lecturers with higher educational qualifications are not good users of ICT facilities. This finding may have been like this because to attain a higher educational qualification, age has a critical role to play. Their age and rank may have been the reason responsible for this finding. In line with this finding, Onasanya, et al (2010) discovered that less experienced lecturers are more exposed to the use of ICT skills than moderately and highly experienced lecturers. The finding of this study also agrees with the results of Lubis, et al (2017) which showed years of teaching experiences and educational level of staff have no significant influence on the utilization of the technology.

The third finding of this study disclosed that a significant influence of lecturers' rank on the utilization of ICT resources for teaching, research and records management exist in higher education. This finding suggests that the utilisation of ICT services decreases as lecturers' rank increases. This finding was attributed to the increasing responsibilities that follows staff of higher academic ranks. For instance, as a graduate assistant, the duties available are relatively few; such a person may be running a Masters or doctorate programme requiring the attention of senior lecturers and is not allowed to teach students at any level. Thus, there is enough time for them to focus on other things such as the utilisation of ICT facilities for either leisure or other purposes (e.g., research). The same may not be said of an associate/full professor or a senior lecturer who has many doctorates, Masters and undergraduate students' research work to assess; has several lectures, conferences and exams scripts to treat; he may be assigned other duties to perform; must publish high-quality papers at his level; attend to other family responsibilities. From the above, it can be seen that there is little or no time left for senior staff to learn how to manipulate ICT devices. Again, an increase in lecturers' rank also moves with a person's age, which makes it possible for some highrank lecturers to be older than many lower rank lecturers (not in all cases). 
Through the fourth finding, it was recorded in this study that there is a significant influence of lecturers' gender on the utilization of ICT resources for teaching, research and records management. Male lecturers utilised ICT resources for teaching, research and records management more than females. The gender disparity recorded in this finding is attributed to the dual roles female African lecturers play in the school and most especially at home. Therefore, the time required for female lecturers to undergo ICT training could be competing with the time needed to take care of the children, domestic issues and attend to other academic demands. It should not sound surprising if male lecturers are using ICT services more than female lecturers. This tallies with the results other studies (e.g., Dholakia et al, 2013; Mahdi \& Al-Dera, 2013) which also brought to the fore that female teachers reported less use of ICT in their instruction than male teachers. The finding, in this section, corroborates the results of some earlier studies which also showed that gender affects ICT utilization (Alakpodia, 2014; John, 2015; Mahdi \& Al-Dera, 2013). The fourth finding, however, challenges the position of some earlier studies (Akpan, 2014; Alba \& Trani, 2018; Amua-Sekyi \& Asare, 2016; Kpolovie \& Awusaku, 2015; Onasanya, et al, 2010) which disagreed and rather posited that gender has nothing to do with the utilization of ICT.

Lastly, it was shown through the fifth finding that there is a significant influence of staff' age on the utilisation of ICT resources for teaching, research and records management in higher education. Younger lecturers demonstrated higher utility of ICT resources in higher education than older lecturers. This finding is unsurprising since younger lecturers are less busy with academic work and may have little or no family responsibility to meet. This aligns with the position of Jegede (2009) that the development of ICT skills, as well as the understanding of ICT services, requires a lot of time and commitment. Only people with sufficient interest and time may be able to cope with such dynamics in ICT (Jegede, 2009). The fifth finding proved the position of Dei (2018) who believed that ICT purely obeys the law of diminishing returns and posited that the utilization of ICT depreciates as an individual grows older. The present study provided a clear piece of evidence that older lecturers are less effective in utilising ICT services, which aligns with the results Manyilizu and Onwuagboke (2015) which also indicated that age is a barrier and has an effect on the use of ICT. It is believed that young people are more desperate to have ICT programs because they are more curious. Contrary to this finding some studies rather show that age does not significantly influence the use of ICT resources (Alba \& Trani, 2018; Amua-Sekyi \& Asare, 2016; Mazoya, et al, 2015). In fact, in a study conducted by Jegede (2009), age was not found to affect the time used on ICT by higher education teachers in Nigeria. The variation in findings arrived at by different scholars may be attributed to factors related to the nature of respondents, actual constructs studied, instruments used or areas where these studies were carried out.

\section{Conclusion}

Based on the findings of this study it was concluded that academic staff personal variables play a significant role on the extent to which staff utilise ICT resources for teaching, research and records management in higher education. These characteristics can make or mar the rate at which staff interact with ICT tools in the school, home or both. Specifically, lecturers' educational qualification, rank, gender and age are very important characteristics that influence the utilization of ICT resources in higher education. By implication, this study has been able to contribute to the ongoing 
academic debate on the influence of gender and age on the utilisation of ICT resources in higher education. The study also creates a new path for prospective researchers to focus on (in areas such as educational qualification and rank). Thus, this study will serve as a reference material to provide a foundation from where more research would be carried out in the future for innovations in education. Based on the conclusion of the study, we recommend as follows:

i. Higher education leaders should make sure that every lecturer has access to available ICT resources in the school.

ii. Lecturers across different ages, gender, educational status and rank should make conscious efforts to avail themselves of the opportunity of becoming ICT literates through active participation in ICT retraining schemes and by putting forth favourable attitudes towards technology.

iii. Retraining channels such as seminars and conferences with a specific focus on improving the ICT skills of lecturers should be organized to all lecturers irrespective of their age, rank, educational qualification or gender. This will enable lecturers to gain full mastery of the procedures needed to utilise ICT devices and resources.

iv. Female lecturers should be encouraged to rise to the challenge by finding time to acquire and implement ICT skills amidst their day-to-day schedules.

v. The three tiers of Government, Non-Governmental Organisations (NGOs), and philanthropist should support the university by providing sufficient ICT materials, facilities, and services such as computer laboratory, modems, internet facilities, projectors, computers, and so on. Such provisions will supplement the retraining offered to lecturers in ICT and make it more impactful. 


\section{References}

Abdulrazaq, B. A. (2016). Effective utilization of ICT for repositioning of library and information science education in tertiary institutions in Nigeria. European Journal of Basic and Applied Sciences, 3(2), 19-26. https://tinyurl.com/t7fp3kr

Abdul-Salaam, A. O. (2012). Assessment of secondary school teachers' use of information and communication technology (ICT) in Oyo Metropolis, Nigeria. Journal Plus Education, 8(1), 179-185. https://tinyurl.com/w24cjfa

Akpan, C. P. (2014). ICT competence and Lecturers' job efficacy in universities in Cross River State, Nigeria. International Journal of Humanities and Social Science, 4(10), 259-266. https://tinyurl.com/qkrrruy

Alakpodia, O. N. (2014). Gender differences in computer use skill among students of the school of health technology, Ufuoma, Delta State. International Journal of Digital Library Services, 11(42), 1-11. https://tinyurl.com/qryot9a

Alba, A. B., \& Trani, L. C. (2018). Extent of utilization of Information and Communication Technology (ICT) by selected secondary school teachers of City Schools Division of Malolos: Basis for the development of a strategic action plan. International Journal of Education and Research, 6(1), 181-188. https://tinyurl.com/txhy8ep

Albion, P. R., Jamieson-Proctor, R., \& Finger, G. (2011). Age-related differences in ICT access and confidence among pre-service teachers. ASCILITE 2011 - The Australasian Society for Computers in Learning in Tertiary Education, 21-32. https://tinyurl.com/swa87sd

Amua-sekyi, E. T., \& Asare, P. Y. (2016). A survey of Information Communication Technology literacy among lecturers. Journal of Education and Practice, 6(8), 1-7. https://tinyurl.com/vs6pbj6

Archibong, I. A., Ogbiji, J. E., \& Anijaobi-Idem, F. (2010). ICT competence among Lecturers in Universities in Cross River State, Nigeria. Science, 3(4), 109-115. https://tinyurl.com/sngmzh2

Ayeni, A. J., \& Ogunbameru, M. (2013). Effective utilization and maintenance of ICT facilities for quality teaching and learning outcome in secondary schools in Ondo State, Nigeria. International Journal of Research Studies in Educational Technology, 2(2), 27-40. https://tinyurl.com/t762w4e

Basri, W. S., Alandejani, J. A., \& Almadani, F. M. (2018). ICT adoption impact on students' academic performance: Evidence from Saudi universities. Education Research International, 9(2), 1-10. https://doi.org/10.1155/2018/1240197

Buza, P., \& Mula, M. (2017). The role of the teachers in the integration of ICT in teaching in secondary low education. European Journal of Social Science Education and Research, 4(4), 240-247.

http://journals.euser.org/index.php/ejser/article/view/2433 
Chiware, T. N. (2006). Effect of Computer-Assisted Instruction (CAI) on economics achievement and retention among senior secondary school students in Kogi State, Nigeria. Unpublished Master Degree Thesis. (University of Nigeria), Nsukka, Enugu State.

Collis, B., \& Moonen, J. (2001). Flexible learning in a digital world: Experiences and Expectations. London: Kogan Page.

Dei, D-G. J. (2018). Assessing the use of Information and Communication Technology in teaching and learning in secondary schools. Library Philosophy and Practice, 1-17 http://digitalcommons.unl.edu/libphilprac/2003

Dholakia, R. R., Dholakia, N., \& Kshetri, N. (2013). Gender and internet usage. In H. Bidgoli (ed.) The Internet Encyclopaedia. New York: Wiley.

Ehikhamenor, F. A. (2002). Internet resources and productivity in Nigerian universities. Journal of Information Science, 29(2), 107-115. https://doi.org/10.1177/016555150302900203

Ejinkeonye, U. B., \& Usoroh, C. I. (2016). Enhancing the utilization of Information Communication Technology (ICT) among Home Economics Lecturers in SouthEastern Nigeria. Journal of Education and Practice, 7(9), 34-39. https://files.eric.ed.gov/fulltext/EJ1095824.pdf

Emeasoba, C. N., \& Nweke, O. M. (2016). Level of availability and utilization of ICT facilities in teaching and learning of OTM in Polytechnics of South-Eastern States in Nigeria. Journal of Emerging Trends in Educational Research and Policy Studies (JETERAPS), 7(6), 404-413. https://tinyurl.com/sx9d3qf

Etim, E. F. (2019). Influence of lecturers' characteristics on the utilization of Information and Communication Technology (ICT) services in the University of Calabar, Calabar, Cross River State, Nigeria. Unpublished B.Ed. Thesis. (University of Calabar), Calabar, Nigeria.

Fomsi, E. F., \& Orduah, S. E. (2017). Gender differences in the use of ICT among teachers in model primary schools in Rivers State, Nigeria. British Journal of Education, 5(4), 88-94. https://tinyurl.com/v6whx8x

Ghavifekr, S., \& Rosdy, W.A.W. (2015). Teaching and learning with technology: Effectiveness of ICT integration in schools. International Journal of Research in Education and Science (IJRES), 1(2), 175-191.

https://files.eric.ed.gov/fulltext/EJ1105224.pdf

Gusen, J. H., Olarin, R. D., \& Garba, E. J. D. (2005). The place of Information and Communication technology in promoting quality assurance in Nigeria University system. International Journal of curriculum organization of Nigeria (CON), 12(3), 25-32. https://files.eric.ed.gov/fulltext/EJ1105224.pdf 
Jegede, P. O. (2009). Age and ICT-related behaviours of higher education teachers in Nigeria. Issues in Informing Science and Information Technology, 6, 771-777. https://doi.org/10.28945/3384

John, S. P. (2015). The integration of information technology in higher education: A study of faculty's attitude towards IT adoption in the teaching process. Contaduria $y$ Administración 60(1), 230-252. http://dx.doi.org/10.1016/j.cya.2015.08.004

Jumbo, M. E. (2019). Lecturers' characteristics on the Utilization of ICTs Services in College of Health Technology, Calabar, Cross River State, Nigeria. International Journal of Innovative Research \& Development 8(8), $72-81$. https://doi.org/10.24940/ijird/2019/v8/i8/AUG19039

Kpolovie, P. J., \& Awusaku, O. K. (2015). ICT adoption attitude of lecturers. European Journal of Computer Science and Information Technology (EJCSIT), 4(5), 9 - 57. https://tinyurl.com/vbfdysr

Lubis, A. H., Idrus, S. Z. S., \& Sarji, A. (2017). The use of ICT among university lecturers in Medan, Indonesia: A Comparative Study. Journal of Human Development and Communication (JoHDEC), 6(1), 63-76. https://tinyurl.com/urmxb9r

Mahdi, H.S. \& Al-Dera, A.S. (2013). The impact of teachers' age, gender and experience on the use of information and communication technology in EFL teaching. English Language Teaching, 6(6), 57-67. https://dx.doi.org/10.5539/elt.v6n6p57

Maisamari, A. M., Adikwu, V. O., Ogwuche, C. O., \& Ikwoche, F. (2018). Assessment of secondary school teachers' use of Information and Communication Technology (ICT) in Anyingba Metropolis, Kogi State, Nigeria. Journal of Education and Entrepreneurship, 5(1), 32-47. https://doi.org/10.26762/jee.2018.40000010

Manyilizu, M. \& Gilbert, G. M. (2015). The use of ICT between male and female teachers in secondary schools in Tanzania: The case of Dodoma Municipality. International Journal of Education and Research, 3(12), 417-428. https://tinyurl.com/sh75veq

Mazoya, A., Ismail, A., \& Manyilizu, M. (2015). Age of teachers vs ICT use in Tanzanian secondary schools: A case of Dodoma Municipality. International Journal of Computer Applications, 132(14), 22-26. https://doi.org/10.5120/ijca2015907579

Munir, S. S., \& Khan, I. (2015). Practices and integration of ICT at private higher secondary level in Pakistan. International Journal on New Trends in Education and Their Implications, 6(2), 104-115. https://tinyurl.com/wbg6w9k

Nwankwoala, H. N. L. (2015). An investigation of lecturers' and students' use of ICTs in Nigerian university education as a panacea for national development. Research on Humanities and Social Sciences, 5(20), 167 - 176. https://tinyurl.com/ruthpvv 
Odigwe, F. N., Bassey, B. A., \& Owan, V. J. (2020). Data management practices and educational research effectiveness of university lecturers in South-South Nigeria. Journal of Educational and Social Research, 10(3), 24-34.

https://doi.org/10.36941/jesr-2020-0042

Onasanya, S.A., Shehu, R.A., Oduwaiye, R.O., \& Shehu, L.A (2010). Higher institutions lecturers' attitudes towards the integration of ICT into teaching and research in Nigeria. Research Journal of Information Technology, 2(1), 1-10. https://doi.org/10.3923/rjit.2010.1.10

Owan, V. J., \& Bassey, B. A. (2019). Data management practices in Educational Research. In N. P. Ololube\& G. U. Nwiyi (Eds.), Encyclopedia of institutional leadership, policy, and management: A handbook of research in honour of Professor Ozo-Mekuri Ndimele (Vol 2, pp. 1251-1265). Port Harcourt, NG: Pearl Publishers International Ltd. https://tinyurl.com/rft9bw3

Owan, V. J., Ekpe, M. B., \& Eneje, S. (2020). Undergraduates' utilisation of social networking media and sexual behaviours in higher education: A case study. Pedagogical Research, 5(2), em0062. https://doi.org/10.29333/pr/7940

Owulu, E. E., Ntamu, G. U., \& Monity, F. M. (2016). ICT utilization and students' academic performance in Christian Religious Studies in Calabar Municipality, Nigeria. The International Journal of Social Sciences and Humanities Invention, 3(11), 2925-2932. https://doi.org/10.18535/ijsshi/v3i11.1

Ramayah, T., Jantan, M., \& Aafaqi, B. (2013). Internet usage among student of an institution of higher learning: The role of motivational variables. Proceedings of the 1st International Conference of Asian Academy of Applied Business conference. https://tinyurl.com/vrz3gxv

Sanda, H. U., \& Kurfi, M. H. (2013). Gender and Information Communication Technologies (ICTS) in Nigeria: Challenges and prospects. Global Journal of Human Social Science, Sociology and Culture, 13(6), 50 - 58. https://tinyurl.com/wjc9x9d

Sani, Y. G., Kamaludeen, I. J., Abbas S. D., Abubakar A. A., \& Abdullahi, S. H. (2016). The use of Information and Communication Technology (ICT) by lecturers in North-Western Nigeria. Computer Engineering and Intelligent Systems, 7(8), 1 - 6. https://tinyurl.com/u2z7vpd

Soffer, T. \& Raban, Y. (2013). Gender and ICTs: Implications for policy and strategy. E-living consortium. https://www.eurescon.de/e-living.com

Unegbu, M. C., Amaechi, N., Njoku, I., \& Opara, I. (2015). Influence of sociodemographic variables on the use of Information and Communication Technology by Lecturers in Library Schools in South-East and South-South Zones of Nigeria. International Journal of Humanities and Social Science Studies (IJHSSS), 2(2), 279289. https://tinyurl.com/sazf5pp

Wong, S.L., Sidek, A. A., Aida, S.M.Y., Zakaria, S., Kamariah, A.B., Hamidah, M., \& Hanafi, A. (2015). Gender differences in ICT competencies among academicians at 
University Putra, Malaysia. Malaysian Online Journal of Instructional Technology, 2(3), 62-69. https://tinyurl.com/w64u8qk

Contact email: owanvalentine@gmail.com francaodigwe@yahoo.com 